\title{
Overheating Reduction in Lightweight Framed Buildings with Application of Phase Change Materials
}

\author{
Eva Zavrl ${ }^{1}$ - Gašper Zupanc ${ }^{2}$ - Uroš Stritih ${ }^{1}$ - Mateja Dovjak ${ }^{2}$,* \\ 1 University of Ljubljana, Faculty of Mechanical Engineering, Slovenia \\ 2 University of Ljubljana, Faculty of Civil and Geodetic Engineering, Slovenia
}

\begin{abstract}
The trend of lightweight framed building structures is gaining in popularity. Due to lower accumulation capability and thermal stability, buildings might be inclined to higher risk of overheating. The purpose of this study is to investigate overheating in lightweight framed buildings from the aspect of thermal comfort and energy efficiency in cooling season. Single-family house was modelled using DesignBuilder ${ }^{\mathrm{TM}}$ and located in moderate climate (Ljubljana, Slovenia). Heavyweight structure was compared to lightweight structure coupled with all 14 variations of phase change materials (PCM). Different strategies of PCM encapsulation (microencapsulated plasterboards, macroencapsulated additional layer), melting points $\left(23^{\circ} \mathrm{C}, 24{ }^{\circ} \mathrm{C}, 25^{\circ} \mathrm{C}, 26^{\circ} \mathrm{C}, 27^{\circ} \mathrm{C}\right.$ ), capacities (M182, M91 M51, M27) and thicknesses (125 mm, $250 \mathrm{~mm}$ ) of PCM were investigated and compared. The best passive solution was primarily evaluated based on the thermal comfort characteristics: average zone operative temperature $\left(T_{0}\right)$ bends in cooling season. Secondarily, the additional energy needed for cooling within each solution was compared to the maximum allowed annual energy consumed for cooling specified in legislation. Consequently, the most influential parameter was the melting point of the PCM structure. Based on the chosen criteria, the overheating was significantly reduced using macroencapsulated layer with melting point of $24{ }^{\circ} \mathrm{C}$ and minimum capacity of $\mathrm{M} 51$ (max. $\mathrm{T}_{0} 26.3^{\circ} \mathrm{C}$ ). Heavyweight structure enabled lower $\mathrm{T}_{0}\left(27.1^{\circ} \mathrm{C}\right)$ in the building compared to microencapsulated plasterboard solution with melting point at $23^{\circ} \mathrm{C}$ and thickness of $250 \mathrm{~mm}\left(28.8^{\circ} \mathrm{C}\right)$. Correctly designed passive solution can be used for the improvement of the design strategy and legislation towards overheating prevention.
\end{abstract}

Keywords: overheating, lightweight framed buildings, phase change materials, thermal comfort, energy efficiency

Highlights

- $\quad$ The study shows that PCM in lightweight structure can completely reduce the energy needed for cooling by decreasing the temperatures for $1.2{ }^{\circ} \mathrm{C}$ more compared to the heavyweight structure.

- When reducing the overheating the heavyweight structure showed results comparable to PCM enhanced lightweight structure with melting point at $25^{\circ} \mathrm{C}$ from the aspect of thermal comfort and energy efficiency.

- $\quad$ Microencapsulated PCM products are not sufficient for reducing the overheating.

- $\quad$ Overheating was completely reduced by using macroencapsulated PCM with melting point of $24^{\circ} \mathrm{C}$ and minimum capacity of M51 in lightweight structure.

\section{INTRODUCTION}

In accordance with the requirements of EU Regulation on construction products [1] are lightweight structures, as a part of building envelope system, describes as "structural loadbearing elements, which have to enable the required mechanical stability, at lower weight than it is general achievable by other heavyweight building structures". It can be reached either by decreasing the amount of material used for structure or by using higher rate of functionality within the lightweight structure [2]. The lightweight framed buildings (hereinafter lightweight buildings) are gaining in popularity in current construction and renovation, mainly due to shorter construction time; lower construction expenses and minimised environmental impact with higher reuse potential [3] and [4]. To control and prevent heat, water and sound transfer, protective layers - constructional products are added, in a function of thermal and sound insulations, waterproofing membrane, vapour barrier, etc.
Additionally, lightweight construction is stimulated in many international and national policies and strategies based on lowering the carbon footprint [5]. The Kyoto protocol pushed the global market trend of lightweight buildings to grow to minimize global warming [2].

Beside economic and environmental advantages, their weakness compared to heavyweight buildings is related to the performance and mutual relation to energy consumption and comfort. Thermally well insulated lightweight framed buildings prevent heat losses through their envelope and perform well when reducing the energy demand over the heating season. However, the heat capacity of the thermal insulation is relatively low. Thus, in summer time, it cannot accumulate the environmental heat. As a consequence, the building lacks thermal stability and its interior overheats [6]. This results in deteriorated thermal comfort over the summer time, also known as overheating.

The climate data show a trend of major global temperature growth [7]. According to the assumptions 
by Intergovernmental Panel on Climate Change (IPPC), due to human activity the global mean surface temperature grew up to $0.8{ }^{\circ} \mathrm{C}$ to $1.2^{\circ} \mathrm{C}$ above mean pre-industrial (1850 to 1900) level. With current grow rate the surface temperatures will increase for $1.5^{\circ} \mathrm{C}$ between 2030 and 2052. Moreover, IPCC reports that the number of heat waves will increase and present a high to moderate risk to health [7]. Consequently, the temperatures in buildings will reach highly dangerous levels for the vulnerable population groups. Since 2014, the trend of heat related symptoms such as heat strokes and deaths was estimated to increase by $66 \%$ until 2020 and $257 \%$ until 2050 [8].

Overheating mainly occurs due to low accumulation capabilities in dwellings, across the entire Europe, even in Northern European countries [9]. Since the overheating of modern lightweight prefabricated structures is an increasingly common problem on a global scale, a large number of scientific researches have recently studied it [6]. Most of the researchers either measured or simulated internal air temperatures or surface temperatures of the peripheral structural layers [10] and [11]. Some also involved the evaluation of thermal comfort with the help of various questionnaires, filled in by the by the occupants [6].

Overheating is regulated by international and national legislation and is based on the qualitative and quantitative criteria of thermal comfort and energy efficiency. For example, CPR 305/2011 defines energy efficiency, hygiene and health needs as basic requirements for building as a whole and for constructional products [1]. European Directive on Energy Performance of Buildings (EPBD 2010/31/ EU) explains that "the permissible annual cooling load required for cooling of residential buildings $Q_{(N C)}$, calculated per unit of cooled area $A_{(u)}$, shall not exceed $50 \mathrm{kWh}$ per year per square meter area $\left(Q_{(N C)} / A_{(u)}\right.$ $\left.\leq 50 \mathrm{kWh} /\left(\mathrm{m}^{2} \mathrm{a}\right)\right)$ " [12]. European requirements are implemented into national legislation. For example, Slovenian rules on efficient energy use in buildings require the maximum permissible value for cooling demand [13]. Similarly, the Slovenian Environmental Public Fund - ECO Fund defines the limit for heating demand for co-funding conditions [14]. On the other hand, the thermal stability of a building is a direct indicator of overheating in correlation to the structural complex. Thermal stability is usually described through air temperature, as suppression factor $v$ or phase delay $\eta$. These values are usually not defined with legislation. However, one of the rear criteria for thermal stability in healthcare facilities is the fraction of the massive structure within the building, published in Spatial Technical Guideline for Health
Facilities in Slovenia, recommended that "at least 25 $\%$ of exterior wall's floor level height should present the massive building material on its inner side" [15]. Moreover, the Slovenian rules on the ventilation and air conditioning of buildings and also American and European standards define the limiting value of operative temperature during the cooling season to be $26{ }^{\circ} \mathrm{C}$ [16] to [18].

Therefore, the strategy for preventing overheating in buildings depends on the building design. In order to prevent and control overheating, comprehensive measures are needed that follow the holistic principles of bioclimatic planning all the way to the introduction of passive and active building systems [19]. Phase change materials (PCM) can be used in buildings as both active or passive systems. Due to their high heat capacity they present an alternative to improve the thermal stability of a lightweight structure, as proved in many studies [10], [11] and [20]. First example of PCM for heat storage applications in buildings in Slovenia presents research by Orel et al. [21]. These studies experimentally and numerically showed that PCM could reduce overheating during the entire year and improve the thermal comfort of the occupants. However, studies evaluated the performance of PCM either on the level of single surface temperature or based on the air temperature. However, air temperature does not report the effect of radiant temperature and is a limited parameter within thermal comfort analyses.

The purpose of this study is to investigate overheating in lightweight buildings from the aspect of thermal comfort and energy efficiency in cooling season. The main criterion for thermal comfort is the operative temperature $\left(T_{\mathrm{o}}\right)$ and for the energy efficiency, the energy cooling demand.

According to the purpose of this research, a model of a typical single-family house was located in a moderate climate. A comparative study of the influence of lightweight and heavyweight structure on overheating of the interior spaces was conducted. Additionally, PCM as passive system for the reduction of overheating problems was applied in the model and tested. The research goals were:

1. To compare four types of exterior walls, namely heavyweight, lightweight, lightweight coupled with additional PCM layer and lightweight with macro encapsulated PCM in plasterboard;

2. To determine the impact of influential parameters of PCM products, namely the encapsulation strategy, melting point, capacity and thickness;

3. To prove that overheating is present, even if the existing criteria (based on the operative 
temperature and energy consumption for cooling) do not indicate it;

4. To define the optimal solution simultaneously within both criteria. The defined solution can then be used for the improvement of the design strategy and legislation.

\section{METHODS}

The comfort is assessed based on air and operative temperature data and the energy efficiency based on the energy consumed for mechanical cooling (active cooling). The chosen case was a family house with net floor area of $177.45 \mathrm{~m}^{2}$, located in moderate climate, Ljubljana Slovenia. The geometry of the building is shown in Fig. 1. The chosen case study presents a typical prefabricated lightweight single-family house, currently expanded on the Slovenian market.

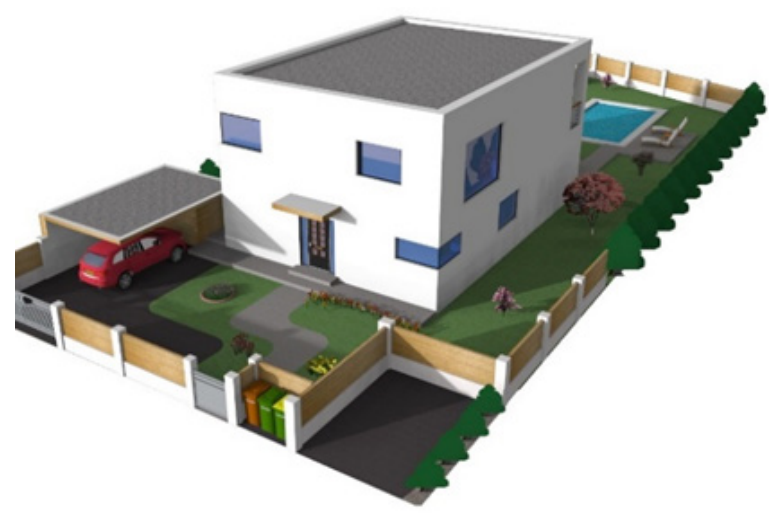

Fig. 1. Front of the building

DesignBuilder ${ }^{\mathrm{TM}}$ v3.4 was used as a calculation tool for the determination of energy consumption (of HVAC, lighting and operation) [22]. The geometry was inserted and the simulation conditions specified as below in Table 1. The model performed calculation within one thermal zone. Most of the data remained unchanged, unless specified otherwise. Different types of structural complexes (SC) of the building's envelope are shown in Figs. 2 to 5 with corresponding characteristic in Table 2. The first type is the heavyweight (HW) type of external wall, which bears the load with a thick layer of the bricks. The second type is the lightweight (LW) SC, which bears the weight with timber elements (frame). In order to improve the thermal capacity characteristics of $\mathrm{LW}, \mathrm{LW}_{\text {PCM.a }}$ and $\mathrm{LW}_{\text {PCM.b }}$ present two different strategies of PCM installation. The strategies vary in PCM location among the layers of SC and in the way that PCM is implemented (macroencapsulated and microencapsulated). The first strategy (designated by symbol ' $a$ ') is macroencapsulated PCM blanket. It is attached as a single additional layer on the inner side of the exterior wall, right after the plasterboard. The second strategy (designated by symbol 'b') is microencapsulated and has a final layer of plasterboard improved with PCM microcapsules. The PCM product used within the first strategy - macroencapsulated additional layer of PCM ( $\mathrm{LW}_{\text {PCM.a }}$ ) is commercially called BioPCM ${ }^{\mathrm{TM}}$.

Table 1. Simulation conditions

\begin{tabular}{|c|c|}
\hline Fixed input data & Value \\
\hline Clothing insulation & $0.5 \mathrm{clo}$ \\
\hline $\mathrm{CO}_{2}$ emissions & $\begin{array}{l}\text { (The amount was defined based } \\
\text { on the function of the space) }\end{array}$ \\
\hline Occupancy rate & 1 \\
\hline Internal heat gains & 1 \\
\hline Air leakage of all SC* & $0.7 \mathrm{ac} / \mathrm{h}$, constant \\
\hline $\begin{array}{l}\text { Thermal transmittance of the } \\
\text { windows }\left(U_{\mathrm{W}}\right)\end{array}$ & $1.058 \mathrm{~W} /\left(\mathrm{m}^{2} \mathrm{~K}\right)$ \\
\hline $\begin{array}{l}\text { Total solar energy transmittance } \\
\text { (g) }\end{array}$ & 0.579 \\
\hline Shading type: & blinds outside \\
\hline \multicolumn{2}{|l|}{ Light gains } \\
\hline Ventilation & hybrid ventilation; $\left(1 \mathrm{ACH}^{\star \star}\right)$ \\
\hline Air conditioning & $\begin{array}{l}\text { The inclusion point was } \\
\text { set when the internal air } \\
\text { temperature exceeded } 26^{\circ} \mathrm{C} \\
\text { and the coefficient of cooling } \\
\text { efficiency was } 3.2\end{array}$ \\
\hline \multirow[t]{2}{*}{ Season } & Summer (1.8. to 7.8.2002) ${ }^{\star \star \star}$ \\
\hline & Whole year 2002 \\
\hline Location & Ljubljana Slovenia \\
\hline PCM melting point (initial) ${ }^{\star \star \star \star}$ & $25^{\circ} \mathrm{C}$ and thickness \\
\hline
\end{tabular}

There are several different melting points available $\left(27{ }^{\circ} \mathrm{C}, 25{ }^{\circ} \mathrm{C}\right.$ and $\left.23{ }^{\circ} \mathrm{C}\right)$ as in product abbreviations 27Q, 25Q and 23Q. Within the chosen melting point, various capacities can be chosen, namely M182, M91, M51, M27 [23] to [25]. BioPCM $^{\mathrm{TM}}$ material is produced out of fatty acids and their derivatives, such as alcohols, amines and esters [26]. Its characteristics are: latent heat $(L)$ : $210 \mathrm{~J} / \mathrm{g}$ to $250 \mathrm{~J} / \mathrm{g}$, energy storage capacity $\left(c_{\mathrm{p}, \mathrm{e}}\right)$ : $400 \mathrm{~kJ} / \mathrm{m}^{2}$ to $1250 \mathrm{~kJ} / \mathrm{m}^{2}$, specific heat $(s): 2.2 \mathrm{~J} /(\mathrm{gK})$ to $4.5 \mathrm{~J} /(\mathrm{gK})$, thermal conductivity $(\lambda): 0.15 \mathrm{~W} /(\mathrm{mK})$ to $2.5 \mathrm{~W} /(\mathrm{mK})$ and relative density $(R D)$ : $0.85 \mathrm{~g} /(\mathrm{mL})$ to $1.4 \mathrm{~g} /(\mathrm{mL})$. The PCM used for the second strategy $\left(\mathrm{PCM}_{\mathrm{b}}\right)$ is a plaster board with addition of microcapsules of paraffin [27]. Characteristics 
of the $\mathrm{PCM}_{\mathrm{b}}$ are: thermal conductivity $(\lambda) 0.23$ $\mathrm{W} /(\mathrm{mK})$, density $(\rho) 880 \mathrm{~kg} / \mathrm{m}^{3}$, board weight $(W)$ $11 \mathrm{~kg} / \mathrm{m}^{2}$ where PCM weights $2 \mathrm{~kg} / \mathrm{m}^{2}$, heat capacity $\left(c_{\mathrm{p}}\right) 12.76 \mathrm{~kJ} /(\mathrm{kgK})$ and $1.17 \mathrm{~kJ} /(\mathrm{kgK})$, melting peak (T) $23{ }^{\circ} \mathrm{C}$ and thickness $(d) 1.25 \mathrm{~cm}$ (commercially determined thickness of the plasterboard). Descriptions of the various SC of the external wall types are shown in Figs. 2 to 5.

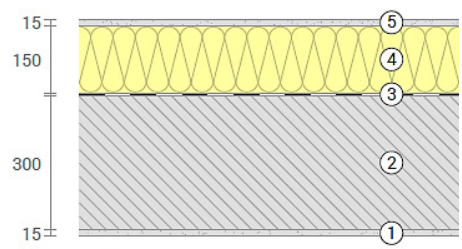

Fig. 2. SC of the external heavyweight wall; (1) plaster $15 \mathrm{~mm}$, (2) brick $300 \mathrm{~mm}$, (3) polyethylene foil, (4) expanded polystyrene, (5) $150 \mathrm{~mm}$, and (6) facade plaster $15 \mathrm{~mm}$

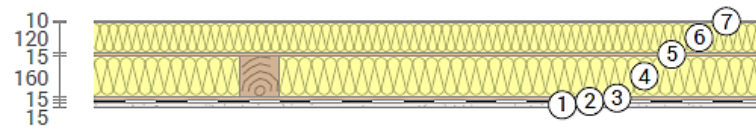

Fig. 3. SC of the external lightweight wall with timber elements; (1) gypsum cardboard $15 \mathrm{~mm}$, (2) polyethylene foil, (3) wooden panel $15 \mathrm{~mm}$, (4) wooden frame with cellulose flakes $160 \mathrm{~mm}$, (5) oriented strand board (OSB) panel $15 \mathrm{~mm}$, (6) mineral wool panels, and (7) facade silicone plaster $10 \mathrm{~mm}$

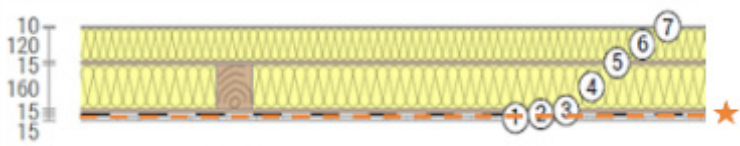

Fig. 4. SC of the external lightweight wall with timber elements with macroencasulated PCM layer; (1) gypsum cardboard $15 \mathrm{~mm}$, *Additional layer of PCM on top of the LW.WF - melting point $25^{\circ} \mathrm{C}$ and thickness of $7.4 \mathrm{~cm}$ (BIO PCM® M182/Q25), (2) polyethylene foil,

(3) wooden panel $15 \mathrm{~mm}$, (4) wooden frame with cellulose flakes $160 \mathrm{~mm}$, (5) oriented strand board (OSB) panel $15 \mathrm{~mm}$, (6) mineral wool panels, and (7) facade silicone plaster $10 \mathrm{~mm}$

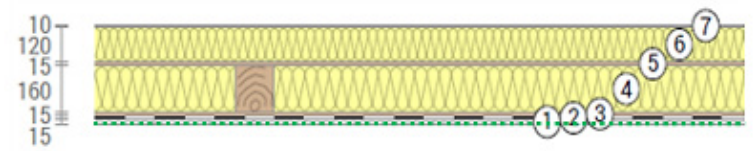

Fig. 5. SC of the external lightweight wall with timber elements with microencasulated PCM in gypsum board; (1) gypsum cardboard with PCM $12.5 \mathrm{~mm}$, (2) polyethylene foil, (3) wooden panel $15 \mathrm{~mm}$,

(4) wooden frame with cellulose flakes $160 \mathrm{~mm}$, (5) oriented strand board (OSB) panel $15 \mathrm{~mm}$, (6) mineral wool panels, and (7) facade silicone plaster $10 \mathrm{~mm}$

Within the simulation, the performance parameters of the structural complexes were determined based on the calculation procedure presented in ISO 7726:1998 [28].
Table 2. Heat transfer coefficients $U\left[W /\left(m^{2} K\right)\right]$ of the designed structural complexes

\begin{tabular}{lcccc}
\hline$U\left[\mathrm{~W} /\left(\mathrm{m}^{2} \mathrm{~K}\right)\right]$ & $H W$ & $L W$ & LW $_{\text {PCM.a }}$ & LW $_{\text {PCM.b }}$ \\
\hline Exterior wall & 0.201 & 0.139 & 0.130 & 0.138 \\
\hline Roof & 0.182 & 0.111 & 0.111 & 0.111 \\
\hline Floor & 0.260 & 0.260 & 0.260 & 0.260 \\
\hline
\end{tabular}

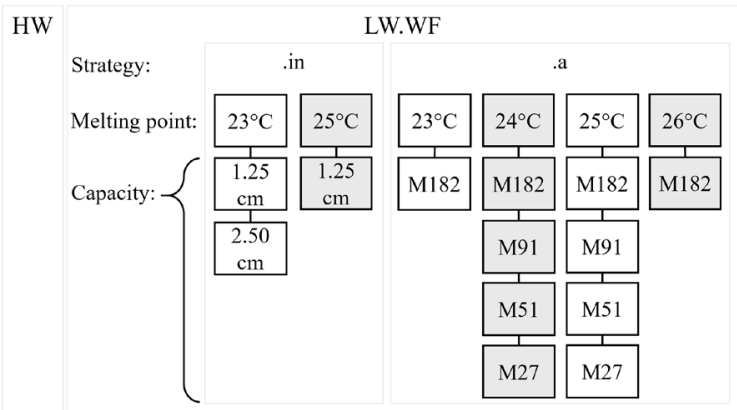

Fig. 6. Systematic scheme of variations investigated and obtained results

Fig. 6 explains the research approach with input data, simulation variations and physical quantities of the results. LW was chosen as a typical representative of the lightweight wooden building where summer overheating occurs. PCM type 'a' and type ' $b$ ' were chosen as standard solution strategies to overcome summer overheating (variation: strategy). PCM solutions applied on LW are compared to the traditional massive building type (HW). In order to investigate the impact of different variations on the results, other variations were tested as well. Within the type ' $a$ ' strategy, the PCM layer of all capacities with various melting point temperatures $\left(23^{\circ} \mathrm{C}\right.$ (PCM.a.23), $24^{\circ} \mathrm{C}$ (PCM.a.24), $25^{\circ} \mathrm{C}$ (PCM.a.25), $26^{\circ} \mathrm{C}$ (PCM.a.26) and $27^{\circ} \mathrm{C}$ (PCM.a.27)) was investigated (variation: melting point temperature). Afterwards, the effect of capacity of PCM.a.25 was tested by decreasing the initial capacities from M182 to M91, M51 and M27 (PCM.a.25.182, PCM.a.25.91, PCM.a.25.51 and PCM.a.25.27 respectively) (variation: heat capacity). Because the comparable PCM product was available only for the melting points of $23{ }^{\circ} \mathrm{C}, 25{ }^{\circ} \mathrm{C}$ and 27 ${ }^{\circ} \mathrm{C}$, the characteristics (enthalpy - air temperature relation) of products with MP at $24{ }^{\circ} \mathrm{C}$ and $26{ }^{\circ} \mathrm{C}$ had to be manually determined. Characteristics of PCM.a.24 (if capacity is not designated, it is referred to as all: 27 to 182) were determined based on the linear interpolation between PCM.a.23 and PCM.a.25 and for PCM26.a.26.182 between PCM.a.25.182 and PCM.a.27.182. Within the second strategy type 'b', two different melting point temperatures were investigated. Similar approach was used to determine 
the characteristics of PCM.b.25, where the properties were extrapolated from PCM.b.23. To validate this method, two simulations were performed. First, the exact values (enthalpy - air temperature relation) obtained from the research by Soares et al. were used to simulate case [29]. Second, the values were extrapolated from PCM.b.23 to the exact case of the plasterboard (PCM.b.23) by following the referred approach. The results obtained from simulating with 2 different types of values had negligible deviations. PCM.b.23 was tested for two thickness, $1.25 \mathrm{~cm}$ and $2.50 \mathrm{~cm}$ (PCM.b.23.125 and PCM.b.23.150, respectively) and PCM.b.25 for one thickness 1.25 cm (PCM.b.25.125). To evaluate the performance of the structural complexes, thermal comfort and energy consumption were investigated. The data were extracted as: outdoor air temperature $\left[{ }^{\circ} \mathrm{C}\right]$, inner air temperature and operative temperature $\left[{ }^{\circ} \mathrm{C}\right]$, delay and overheating recalculated out of $T_{\mathrm{ai}}$ and $T_{\mathrm{o}}[\mathrm{h}]$ and the energy consumed for cooling the building [kWh] when $T_{\mathrm{ai}}$ and $T_{\mathrm{o}}$ exceeded the recommended limit. The upper and lower limits of $T_{\mathrm{ai}}$ and $T_{\mathrm{o}}$ were defined within Category III of indoor environment during the cooling season determined in EN15251:2007 [18]. The upper and lower limits for $T_{\text {ai }}$ are $26^{\circ} \mathrm{C}$ and $23^{\circ} \mathrm{C}$ and for $T_{\mathrm{o}} 27^{\circ} \mathrm{C}$ and $22^{\circ} \mathrm{C}$, respectively. The same limits stand when determining the electricity consumed for cooling to keep the building running within these limits. The electricity - electrical chiller is in case of thermal comfort investigations switched OFF and in case of energy efficiency investigations turned $\mathrm{ON}$. The results are presented for the $1^{\text {st }}$ week of August (as the week with the highest outdoor air temperatures of the TRY) and for the entire year. List of variations: HW; LW; LW.PCM.a.23: M182/Q23; LW.PCM.a.24: M182/ Q24, M91/Q24, M51/Q24 and M27/Q24; LW.PCM.a.25: M182/Q25, M91/Q25, M51/Q25 and M27/Q25; LW.PCM.a.26: M182/Q26; LW.PCM.a.27: M182/Q27; $\mathrm{LW}_{\text {PCM.b.23 }}$ : two thicknesses of $1.25 \mathrm{~cm}$ and $2.50 \mathrm{~cm}$ and $\mathrm{LW}_{\text {PCM.b.25: }}$ thickness of $1.25 \mathrm{~cm}$.

\section{RESULTS}

The results of the analysis of overheating from the aspects of thermal comfort are presented with operative temperatures. The energy cooling demand is defined with $\left[\mathrm{kWh} / \mathrm{m}^{2}\right]$ needed for cooling.

\subsection{Evaluation of Thermal Comfort Based on Operative Temperatures $T_{\mathrm{o}}$}

Fig. 7 shows the outdoor air temperature $\left(T_{\mathrm{ao}}\right)$ which presents the environmental conditions during which
$T_{\mathrm{ai}}$ and $T_{\mathrm{o}}$ were measured. The horizontal dash line shows maximum $\left(27^{\circ} \mathrm{C}\right)$ operative temperature for obtaining the thermal comfort in the summer time determined in EN15251:2007 (static method) [18]. The first column set always shows the maximum temperatures obtained and the second column set the minimum temperatures obtained. The graphs always show operative temperatures on y-axis, but in case of 'Outside Dry-Bulb Temperature', where air temperatures are presented. The other two columns present the types of building external wall structures without PCM. The operative temperatures obtained in the space with the heavyweight wall (HW) are presented by the diagonal line patterned column and the lightweight wooden frame (LW) is presented with light grey column.
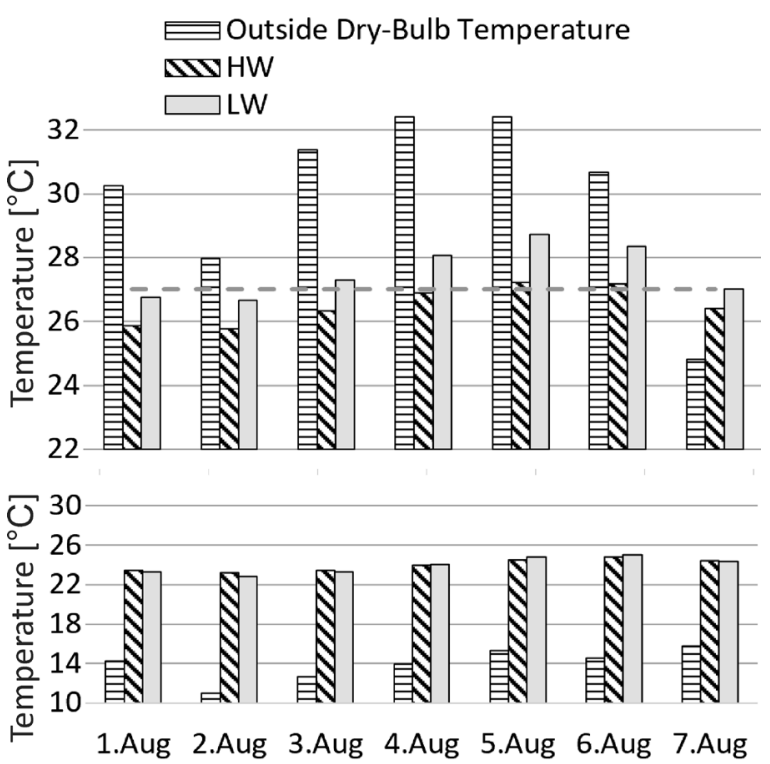

Fig. 7. Temperatures $\left[{ }^{\circ} \mathrm{C}\right]$ obtained with $H W$ and $L W$ structure during the $1^{\text {st }}$ week of Aug (max. temperatures in $1^{\text {st }}$ set of columns and min. temperatures in $2^{\text {nd }}$ )

The results indicate that the $T_{\mathrm{o}}$ of the HW structure slightly (max. $+0.2^{\circ} \mathrm{C}$ ) exceeded the upper limit of $27^{\circ} \mathrm{C}$ on $5^{\text {th }}$ of Aug (14:00 to $18: 00 \mathrm{~h}$ ) and Aug, $6^{\text {th }}$ of Aug (13:00 to $\left.16: 00 \mathrm{~h}\right)$. The maximum $T_{\mathrm{o}}$ reached with $\mathrm{LW}$ structure is $28.7^{\circ} \mathrm{C}$ on the $5^{\text {th }}$ of Aug at 17:00. However, the temperature exceeded the upper limit also on the $4^{\text {th }}, 6^{\text {th }}$ and $7^{\text {th }}$ of Aug. Compared to LW, the HW structure alone, was less responsive to the outdoor temperature fluctuations.

Fig. 8 shows the results obtained with the LW structure alone and with PCM strategy type b - microencapsulated gypsum boards. The melting points were at $23{ }^{\circ} \mathrm{C}(1.25 \mathrm{~cm}$ and $2.50 \mathrm{~cm})$ and at $25^{\circ} \mathrm{C}(1.25 \mathrm{~cm})$. Compared to $\mathrm{LW}$, the application of 
microencapsulated PCM with the melting point of $23^{\circ} \mathrm{C}$ and thickness of $1.25 \mathrm{~cm}\left(\mathrm{LW}_{\text {PCM.b.23.125 }}\right)$ does not affect the temperature fluctuations. The peak temperature is reached at $28.8{ }^{\circ} \mathrm{C}$ at $17: 00$ (5th of Aug). Similar was shown with $\mathrm{LW}_{\text {PCM.b.23.250, where }}$ the double thickness negligibly softened the main temperature peak to $28.6^{\circ} \mathrm{C}$. Thus, the melting point of $23{ }^{\circ} \mathrm{C}$ is inappropriate choice for such building type and such climate conditions. On the other hand, the usage of $\mathrm{LW}_{\text {PCM.b.25.125 }}$ slightly reduced the daily maximum temperatures. The main peak from $5^{\text {th }}$ of Aug was reduced by $0.8^{\circ} \mathrm{C}$ (to $27.9^{\circ} \mathrm{C}$ ).

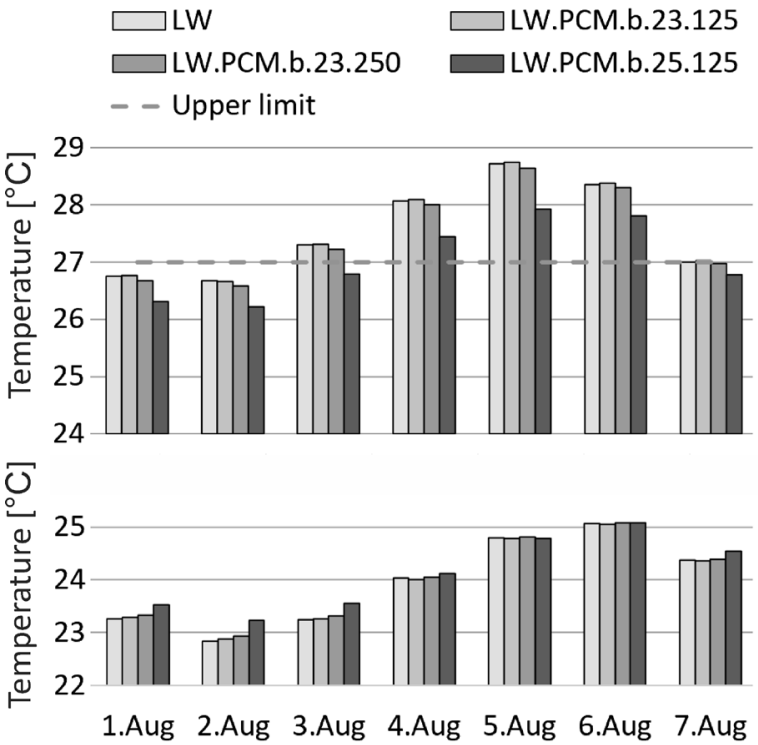

Fig. 8. $T_{0}\left[{ }^{\circ} \mathrm{C}\right]$ obtained with microencapsulated (.b) strategy during the $1^{\text {st }}$ week of Aug (max. temperatures in 1 st set of columns and min. temperatures in $2^{\text {nd }}$ )

Fig. 9 shows the performance of strategy type a- the additional layer of macroencapsulated PCM on the inner side of the exterior walls at five different melting points $\left(23^{\circ} \mathrm{C}, 24{ }^{\circ} \mathrm{C}, 25^{\circ} \mathrm{C}, 26^{\circ} \mathrm{C}\right.$ and $\left.27^{\circ} \mathrm{C}\right)$ within single capacity (M182).

Compared to LW, the macroencapsulated strategy with the melting point of $23^{\circ} \mathrm{C}$ (LWPCM.a.23.182) reduced $T_{o}$ during the first exceeding peak (4th of Aug at $17: 00$ ) by $0.6{ }^{\circ} \mathrm{C}$ (from $28.1{ }^{\circ} \mathrm{C}$ to $27.5{ }^{\circ} \mathrm{C}$ ). However, the second and the third peak were not affected (5th of Aug (17:00 h) and 6th of Aug (15:00 h)). LWPCM.a.25.182 and LWPCM.a.26.182 fluctuated similarly. The maximum $T_{o}$ obtained was close to the upper limit. On 5th of Aug (17:00 h), with PCM.a.25.182 and LWPCM.a.26.182, the obtained max. To were $27.3{ }^{\circ} \mathrm{C}\left(-1.5{ }^{\circ} \mathrm{C}\right)$ and $27.0{ }^{\circ} \mathrm{C}(-1.8$ ${ }^{\circ} \mathrm{C}$ ), respectively. LWPCM.a.24.182 could sufficiently decrease the maximum $T_{o}$ during the hottest week of the year below the upper limit.
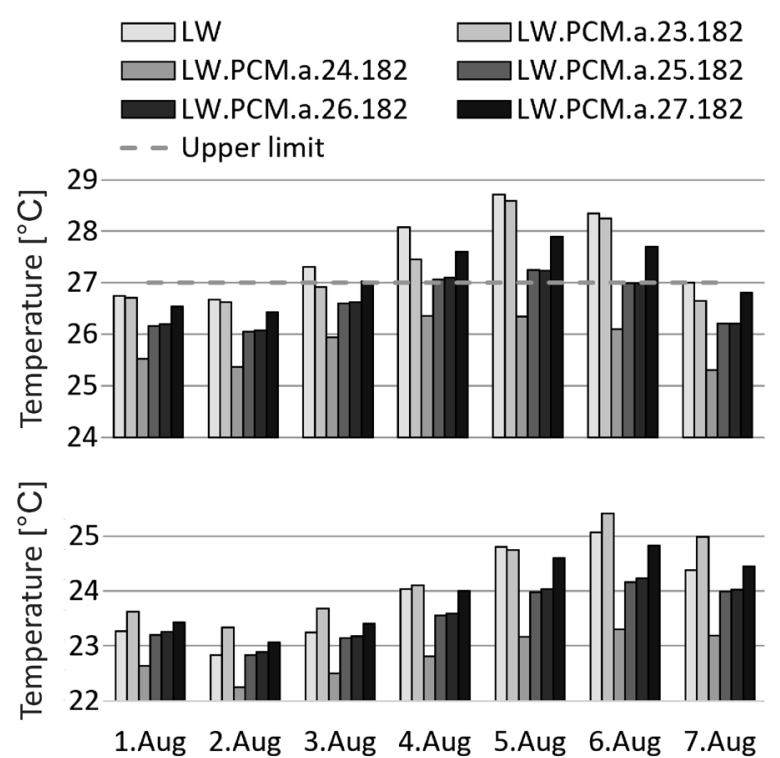

Fig. 9. $T_{0}\left[{ }^{\circ} \mathrm{C}\right]$ obtained with macroencapsulated (.a) strategy during the 1st week of Aug (max. temperatures in 1st set of columns and min. temperatures in $2^{\text {nd }}$ )

Both strategies (' $b$ ' and ' $a$ ') within the melting point of $23{ }^{\circ} \mathrm{C}$ compared are shown in Fig. 10 .

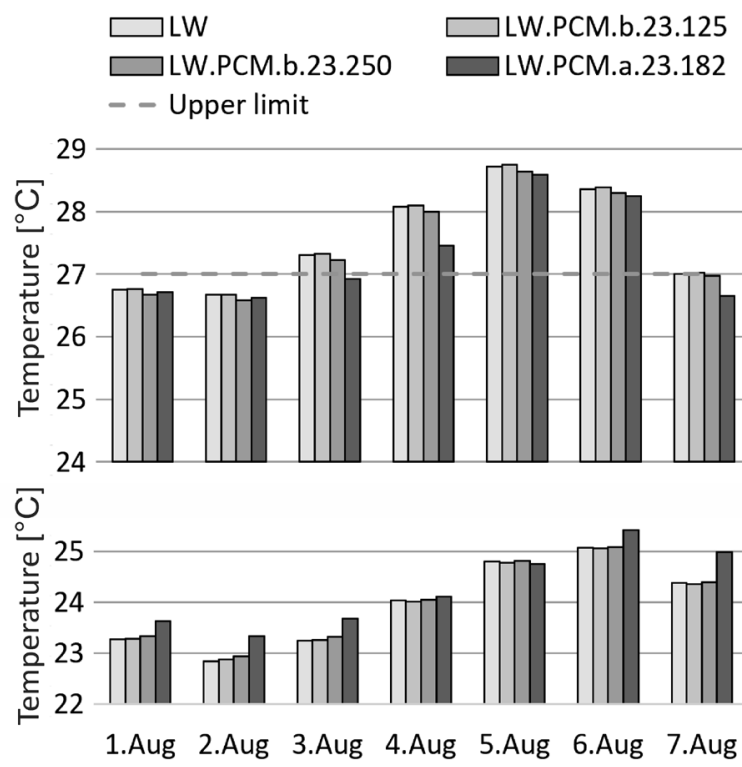

Fig. 10. $T_{0}\left[{ }^{\circ} \mathrm{C}\right]$ obtained with both PCM strategies with the melting point of $23^{\circ} \mathrm{C}$ during the 1 st week of Aug (max. temperatures in $1^{\text {st }}$ set of columns and min. temperatures in $2^{\text {nd }}$ )

$\mathrm{LW}_{\text {PCM.a.23.182 }}$ has the highest capacity among all cases shown in Fig. 10. Regardless from its high accumulation capabilities, it buffers only the first 
peak, but not the last two (5th and $6^{\text {th }}$ of Aug). In addition to the figures above (Figs. 7 to 9), it could be concluded that, the mis-determination of the melting point cannot be corrected to the addition of thermal capacity. $\mathrm{LW}_{\text {PCM.a.25.182 }}$ is an existing product with three lower capacities available (M91, M51 and M27) (Fig. 11).
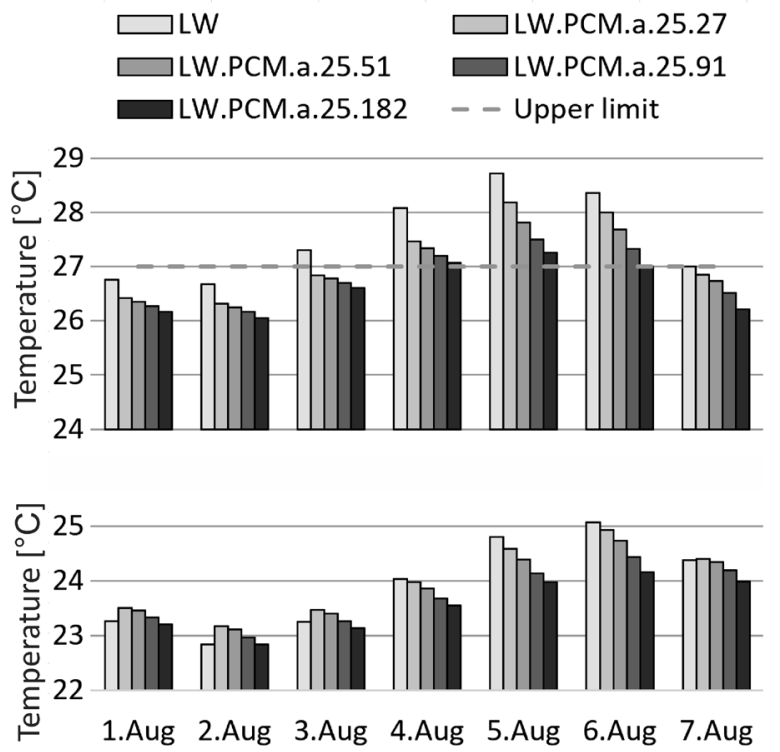

Fig. 11. $T_{0}\left[{ }^{\circ} \mathrm{C}\right]$ obtained with $L W_{P C M . a .25}$ and various heat capacities during the $1^{\text {st }}$ week of Aug (max. temperatures in $1^{\text {st }}$ set of columns and $\mathrm{min}$. temperatures in $2^{\text {nd }}$ )

In Fig. 10, different capacities had almost no effect on the performance of the PCM. From Fig. 11 it is clear, that lower capacities within the same melting point affected the results. All of the peaks from the $4^{\text {th }}$ to the $7^{\text {th }}$ of Aug would increase with decreasing capacity. This is most clear within the highest peak from the $5^{\text {th }}$ of August, where $T_{\mathrm{o}}$ would increase from $27.3^{\circ} \mathrm{C}$ to $27.5^{\circ} \mathrm{C}, 27.8^{\circ} \mathrm{C}$ and $28.2^{\circ} \mathrm{C}$ with $\mathrm{M} 91$, M51 and M27, respectively. The performance of $\mathrm{LW}_{\text {PCM.a.25.91 }}$ is similar to the thermal performance of HW.

In Fig. 12, the variations of different capacities of $\mathrm{LW}_{\text {PCM.a.24.182 }}$ are presented. The question is, what is the lowest capacity that can still keep the temperatures below the upper limit.

On the $5^{\text {th }}$ of Aug (17:00 h), $\mathrm{LW}_{\text {PCM.a.24.182 }}$ reduced the maximum peak of $\mathrm{LW}$ by $2.4^{\circ} \mathrm{C}$ (from $28.7^{\circ} \mathrm{C}$ to $26.3^{\circ} \mathrm{C}$ ). $\mathrm{LW}_{\text {PCM.a.24 }}$ can keep $T_{\mathrm{o}}$ peaks below the upper limit in all studied cases, except in the case with the lowest capacity investigated ( $\mathrm{LW}_{\text {PCM.a.24.27). }}$. With the case of LW $_{\text {PCM.a.24 }}$, the importance of the well-chosen melting temperature is stressed. In this way, also the costs of the material could be reduced.

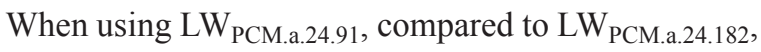
$T_{\mathrm{o}}$ fluctuations remained almost unchanged. The maximum $T_{\mathrm{o}}$ obtained was $26.5^{\circ} \mathrm{C}$, which is only 0.2 ${ }^{\circ} \mathrm{C}$ higher compared to M182. With $\mathrm{LW}_{\text {PCM.a.24.51 }}, T_{\mathrm{o}}$ remained below the upper limit, but the maximum increase was to $26.9^{\circ} \mathrm{C}$, which is nearly the upper limit. The capacity of LW $_{\text {PCM.a.24.27 }}$ would not be large enough to hold $T_{\mathrm{o}}$ below the limit. Thus the maximums exceed it up to $28.2{ }^{\circ} \mathrm{C}$. The fluctuations in Figs. 11 and 12 were similar, without any phase delays.
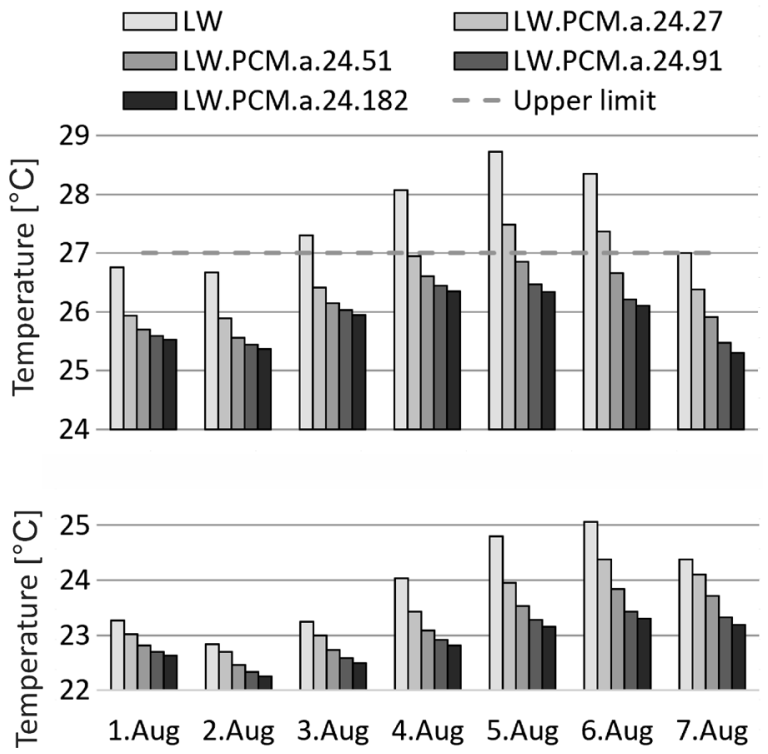

Fig. 12. $T_{0}\left[{ }^{\circ} \mathrm{C}\right]$ obtained with $L W_{P C M . a .24}$ and various heat capacities during the $1^{\text {st }}$ week of Aug (max. temperatures in $1^{\text {st }}$ set of columns and $\mathrm{min}$. temperatures in $2^{\text {nd }}$ )

\subsection{Energy Efficiency Evaluated Based on the Hours of Overheating}

Table 3 shows the number of hours above which the upper air temperature $\left(T_{\text {ai }}\right)$ and operative temperature $\left(T_{\mathrm{o}}\right)$ limits were higher than the defined upper limit. Table 3 shows the hours for the two existing products that were closest to the real usage.

Table 3. The number of hours of overheating $(\mathrm{OH})[\mathrm{h}]$ based on $T_{\mathrm{ai}}$ in $T_{\mathrm{o}}$ (1st week of August)

\begin{tabular}{ccccc}
\hline Type & HW & LW & $\begin{array}{c}\text { LWPCM } \\
\text { a.25.182 }\end{array}$ & $\begin{array}{c}\text { LWPCM } \\
\text { b.23.125 }\end{array}$ \\
\hline$T_{\mathrm{ai}}>26^{\circ} \mathrm{C}$ & 51 & 66 & 48 & 66 \\
\hline$T_{\mathrm{o}}>27^{\circ} \mathrm{C}$ & 6 & 30 & 6 & 30 \\
\hline
\end{tabular}

Besides $T_{\mathrm{o}}$, Table 3 includes also $T_{\mathrm{ai}}$, as the $T_{\mathrm{o}}$ limit is chosen for Category III of indoor environment 
and could thus be misleading (inaccurate) [18]. As can be seen from Table 3, the number of $\mathrm{OH}$ varies strongly in dependence of the strategy. Overheating occurred in both chosen existing cases. Consequently, the building's interior was overheated. The $\mathrm{OH}$ was zero in non-existing cases of LW $_{\text {PCM.a.24.182, }}$

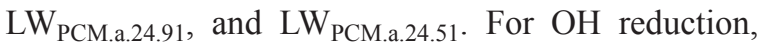
additional cooling with active system is required. Table 4 shows the amount of electrical energy needed to cool the rest of the existing products ( $\mathrm{LW}_{\text {PCM.b.23.125 }}$ and $\mathrm{LW}_{\text {PCM.a.25.182). }}$.

Table 4. Amount of electrical energy needed for cooling $Q_{(N C)} / A_{(u)}\left[\mathrm{kWh} / \mathrm{m}^{2}\right]$

\begin{tabular}{lcccc}
\hline Type & HW & LW & $\begin{array}{c}\text { LWPCM } \\
\text { a. } 25.182\end{array}$ & $\begin{array}{c}\text { LWPCM } \\
\text {.b.23.125 }\end{array}$ \\
\hline $\mathrm{Q}_{1 \text { st.A }}$ & 1.4 & 1.5 & 1.3 & 1.5 \\
\hline $\mathrm{Q}_{\mathrm{y}}$ & 7.4 & 9.7 & 8.4 & 9.6 \\
\hline $\mathrm{Q}_{1 \text { st.A }}-\mathrm{Q}_{\mathrm{y}}$ & $19 \%$ & $16 \%$ & $15 \%$ & $16 \%$ \\
\hline
\end{tabular}

\subsection{Energy Performance Evaluated Based on the Energy Consumed for Cooling}

Table 4 presents the energy needed to cool the building to the required operative temperature limits with electric chiller for the 1 st week of $\operatorname{Aug}\left(\mathrm{Q}_{1 \text { st.A }}\right)$ and for the entire year $\left(\mathrm{Q}_{\mathrm{y}}\right)$, per $\mathrm{m}^{2}$ of the building. The importance of the $1^{\text {st }}$ week of August is shown in the last row of the table (the percentage of energy consumed for cooling over the first week compared to the entire year), where it is specified that up to $19 \%$ of the total yearly cooling demand can be consumed in the first week of August. The correctly chosen passive system (LW ${ }_{\text {PCM.a.24.182; }} \mathrm{LW}_{\text {PCM.a.24.91 }}$ and $\mathrm{LW}_{\text {PCM.a.24.51 }}$ ) could reduce the yearly demand by $16 \%$ or more.

\section{DISCUSSION}

Within the first few days (1 1 st to $3^{\text {rd }}$ of Aug), in all of the investigated cases the temperatures remained below the upper limit of thermal environment. On the $4^{\text {th }}$ of Aug, in most of the cases (exception is $\mathrm{LW}_{\text {PCM.a.24), }}$ ), $T_{\mathrm{o}}$ grew above the upper limit at 13:00 h. On the next day, $5^{\text {th }}$ of Aug, $T_{\mathrm{o}}$ of all the cases exceeded the upper limit and also reached the peak with 1 or 2 hour delay. Afterwards ( $6^{\text {th }}$ and 7 th of Aug), $T_{\mathrm{o}}$ started to decrease. In order to compare the PCM solution to overheating with the traditional building concept, the comparison of the daily $T_{\mathrm{o}}$ peaks of various lightweight framed building combinations to the heavyweight building should be performed (Table 5). When observing the performance of HW structure during the highest daily peaks, it is possible to observe that during the cooler days (1 ${ }^{\text {st }}$ to $3^{\text {rd }}$ of Aug) the HW structure could reach lower temperatures than in the rest of the cases (exc. $\left.\mathrm{LW}_{\text {PCM.a.24 }}\right)$, as apparently the material used for its mass (brick) accumulates the heat better than the PCM with chosen melting points. However, from the $4^{\text {th }}$ of August on (5th to $7^{\text {th }}$ of Aug), the HW structure could not keep the temperature peaks lower than in the cases with PCM with melting points of $25^{\circ} \mathrm{C}$ and $26^{\circ} \mathrm{C}$ ( $\mathrm{LW}_{\text {PCM.a.25.182 }}$ and $\mathrm{LW}_{\text {PCM.a.25.91 }}$ and $\mathrm{LW}_{\text {PCM.a.26.182). }}$ ). Also other studies [6], [10], [30] to [33] reported that lightweight assembly compared to heavyweight assembly showed higher air temperatures within identical external conditions.

Table 5. Temperature differences $T_{\mathrm{o}}\left[{ }^{\circ} \mathrm{C}\right]$ of the maximum $T_{\mathrm{o}}$ obtained with $\mathrm{HW}$ and optional case showing positive values

\begin{tabular}{|c|c|c|c|c|c|c|c|c|}
\hline $\begin{array}{l}\sum_{0}^{\circ} \\
\text { ì }\end{array}$ & 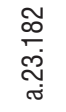 & 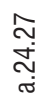 & 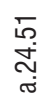 & 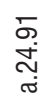 & 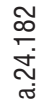 & $\begin{array}{l}\bar{\sigma} \\
\stackrel{\sim}{\sim} \\
\text { d }\end{array}$ & 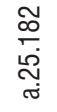 & $\frac{\widetilde{D}}{\infty}$ \\
\hline Aug 1 st & -0.6 & 0.0 & 0.2 & 0.4 & 0.4 & -0.3 & -0.2 & -0.3 \\
\hline Aug 2nd & -0.3 & 0.0 & 0.2 & 0.3 & 0.4 & -0.3 & -0.2 & -0.2 \\
\hline Aug $3^{\text {rd }}$ & -0.5 & 0.0 & 0.3 & 0.4 & 0.5 & -0.2 & -0.1 & -0.1 \\
\hline Aug $4^{\text {th }}$ & -0.5 & 0.1 & 0.4 & 0.5 & 0.6 & -0.2 & -0.1 & 0.1 \\
\hline Aug $5^{\text {th }}$ & -0.9 & 0.0 & 0.4 & 0.8 & 0.9 & -0.1 & 0.0 & 0.2 \\
\hline Aug $6^{\text {th }}$ & -0.8 & 0.0 & 0.6 & 1.0 & 1.2 & 0.0 & 0.2 & 0.9 \\
\hline Aug $7^{\text {th }}$ & 0.2 & 0.2 & 0.6 & 1.0 & 1.1 & 0.1 & 0.3 & 0.6 \\
\hline
\end{tabular}

The next group of the results is the minimum temperatures obtained in the night time. The minimum temperatures were obtained in the night time, but they never dropped below the lower limit. During the night time, in all of the cases the temperatures were suitable for occupant's sleep.

The first influential parameter of the PCM solution is the strategy. For example, Vik et al. found that $17 \mathrm{~m}^{2}$ (Q23/M51) applied on the wall and ceiling of an office of $15 \mathrm{~m}^{2}$ floor area reduced the $T_{\mathrm{o} \text {,max }}$ by about $2{ }^{\circ} \mathrm{C}$ or even more, when facing the occupant [34].

The second influential parameter is the melting point. The effect of different melting points was tested. It was shown that the effect of the melting point is stronger compared to the effects of the other two influential parameters (strategy and capacity). Similar findings were mentioned by other studies, such as Pajek et al. [10]. Further, Reddy et al. [35] investigated the temperature of the inside (base) layer in the roof of a building located in Chennai (India) with different melting temperatures, thicknesses and numbers of PCM layers (single- or multi-layer) by using computer 
fluid dynamics (CFD). They showed that when choosing the correct PCM melting point combination, the temperature of the layer remained unchanged during the whole daily cycle, even when changing the thicknesses of the PCM layers. The studies support the present findings and expose the importance of the correctly chosen melting point temperatures.

The studies are also in agreement with the conclusions regarding the capacity. The capacity should be large enough to absorb the excess heat and keep the temperatures below the upper limit. If the capacity is too low (i.e. $\mathrm{LW}_{\text {PCM.a.24.27), then } T_{\mathrm{o}} \text { will }}$ exceed the comfortable indoor levels. If the capacity is too high (and the strategy and melting point suitable), then the solution is not cost and environmentally optimised. The surplus of the material results in deterioration of the LCA grade for the entire building complex. There is the possibility of self-insulation. As a result, over night the excess material is not completely solidified.

Additionally, the solidification of the PCM may be increased by increasing the ventilation rate in the building. Higher amounts of conditioned (cooled) air remove the heat from the PCM with convection and in this way accelerate its solidification. The increased performance of the PCM was additionally proven within some of the studies [10]. Moreover, the increased volume flow rate often results in higher velocities in the occupied zones. This affects the thermal comfort (i.e. $T_{\mathrm{o}}$ ) and may cause draught to the occupants. However, the energy consumed for the preparation of additional inlet air increases, which results in higher energy consumption for cooling.

Overheating hours as one of the analysed indicators of the presence of the overheating, numerically specifies the $\mathrm{OH}$. Another possibility is coupling the passive strategy with the active one. The number of hours may be determined also with other criteria, such as improved weather files for heat wave analysis [36] or focusing on the periods outside the heat waves when the heat is accumulated in the environment [37].

Energy performance shows the amount of energy needed for cooling during certain period. The results of this study correlate with other studies, proving that the correct application of PCM decreased the electrical consumption for cooling. For example, it was shown that a correct usage of PCM can improve overheating reduction from $7 \%$ to $34 \%$ [38]. A similar numerical study performed in TRNSYS showed that the PCM in walls combined with thermal insulation reduced the energy costs up to $66.2 \%$ compared to the uninsulated envelope without PCM [39]. Reddy et al. showed that using double layered PCM (25\% to $35 \%$ ) reduced the heat gains more, compared to single layer PCM (17\% to $26 \%$ ) [35].

The limitations of this study are: lack of CFD simulation within the zones, a lack of experimental measurements, the model does not consider the heatwaves. In this stage of our research we focused on one building case study with different building envelopes, where material properties (strategy, capacity and melting point) were variated.

\section{CONCLUSIONS}

To prevent overheating, a holistic approach based on bioclimatic design principles is needed, where the building is adapted to climate and location characteristics [19] and [40]. Secondly, a passive system with PCM (system) should be introduced to attain its maximum potential and system efficiency. Based on the study it can be concluded that:

- The presented system can increase the thermal comfort of the building and reduce the cooling demand;

- Results of this study showed that the macroencapsulated layer with melting point of $24{ }^{\circ} \mathrm{C}$ and minimum capacity of M51 results in simultaneous attainment of cooling demand (1.25 $\mathrm{kWh} / \mathrm{m}^{2}$ ) and thermal comfort conditions with lower operative temperature $\left(\max . T_{\mathrm{o}} 26.3{ }^{\circ} \mathrm{C}\right)$;

- With precise selection of influential parameters (melting point, capacity/thickness) the operative temperatures and energy consumption of lightweight structure are decreased more than in heavyweight structure;

- In order to attain its highest efficacy, it is important to select PCM with optimum melting point temperature, since the mis-determination of the melting point cannot be corrected by the addition of thermal capacity (the melting point at $23{ }^{\circ} \mathrm{C}$ has almost no effect on the performance of the lightweight structure and couldn't reduce the overheating at both thicknesses tested);

- The combinations of PCM with multi-layers of different melting points may also be applied in order to cover different temperature ranges;

- Macroencapsulated strategy has the potential to increase the capacity and is thus, more practical for usage;

- The system is highly applicable for the renovation of existing lightweight buildings or geometrically complex structures in the building envelope, by not losing the delicate amount of the floor area in the building; 
In the future, the effectiveness of PCM operation should be investigated. The combination of numerical model on micro-scale and macro-scale and also a material for both cooling and heating season will be investigated considering [20]. Furthermore, the research should focus on material discharge (night-time ventilation or water pipe system in the neighbouring layer) and modelling the most efficient combination of a two PCM layers with different melting points. Nevertheless, the system should be investigated in the realistic environment of the singlefamily house. Also, another subject of further research should be the improvement of international and national legislation in order to define, qualitatively and quantitatively, indicators for the prevention of overheating. The indicators should be specified on the level of buildings, building systems and the environment, including the characteristics of: shading, transparent and non-transparent parts of building envelope (thermal stability, delays, accumulation capabilities, etc.). Active solutions should be coupled with bioclimatic and passive solutions and the limit amount of electricity consumed for cooling with mechanical systems should be defined.

\section{ACKNOWLEDGEMENTS}

The authors acknowledge the financial support from the Slovenian Research Agency (research core funding No. P2-0158, Structural engineering and building physics and No. P2-0223, Heat and Mass Transfer).

\section{NOMENCLATURES}

\begin{tabular}{ll}
$\rho$ & density, $\left[\mathrm{kg} / \mathrm{m}^{3}\right]$ \\
$c_{\mathrm{p}, \mathrm{e}}$ & energy storage capacity, $\left[\mathrm{kJ} / \mathrm{m}^{2}\right]$ \\
$c_{\mathrm{p}}$ & heat capacity, $[\mathrm{J} /(\mathrm{kgK})]$ \\
$d$ & thickness, $[\mathrm{cm}]$ \\
$g$ & total solar energy transmittance, $[-]$ \\
$L$ & latent heat, $[\mathrm{J} / \mathrm{g}]$ \\
$\lambda$ & thermal conductivity, $[\mathrm{W} /(\mathrm{mK})]$ \\
$\mathrm{OH}$ & number of hours of overheating, $[\mathrm{h}]$ \\
$R D$ & relative density, $[\mathrm{g} /(\mathrm{mL})]$ \\
$S$ & specific heat, $[\mathrm{J} /(\mathrm{gK})]$ \\
$T$ & melting peak, $\left[{ }^{\circ} \mathrm{C}\right]$ \\
$T_{\mathrm{ai}}$ & indoor air temperature, $\left[{ }^{\circ} \mathrm{C}\right]$ \\
$T_{\mathrm{ao}}$ & outdoor air temperature, $\left[{ }^{\circ} \mathrm{C}\right]$ \\
$T_{\mathrm{o}}$ & operative temperature, $\left[{ }^{\circ} \mathrm{C}\right]$ \\
$T_{\mathrm{o}, \mathrm{max}}$ & maximum operative temperature, $\left[{ }^{\circ} \mathrm{C}\right]$ \\
$Q_{(N C)} / A_{(u)}$ amount of electrical energy needed \\
\multicolumn{2}{c}{ for cooling, $\left[\mathrm{kWh} / \mathrm{m}^{2}\right]$} \\
$Q_{1 \text { st.A }}$ & electrical energy needed for cooling during
\end{tabular}

the $1^{\text {st }}$ week of Aug, $\left[\mathrm{kWh} / \mathrm{m}^{2}\right]$

$Q_{\mathrm{y}} \quad$ electrical energy needed for cooling during the entire year, $\left[\mathrm{kWh} / \mathrm{m}^{2}\right]$

$Q_{1 \text { st.A-Qy }}$ energy consumed for cooling over the $1^{\text {st }}$ week compared to the entire year, [\%]

$W \quad$ weight, $\left[\mathrm{kg} / \mathrm{m}^{2}\right]$

$U$ heat transfer coefficient, $\left[\mathrm{W} /\left(\mathrm{m}^{2} \mathrm{~K}\right)\right]$

$U_{\mathrm{W}} \quad$ thermal transmittance of the windows, $\left[\mathrm{W} /\left(\mathrm{m}^{2} \mathrm{~K}\right)\right]$

$v \quad$ temperature suppression factor, [-]

$\eta \quad$ phase delay, $[\mathrm{h}]$

\section{REFERENCES}

[1] CPR no. 305/2011. Regulation (EU) No 305/2011 of the European Parliament and of the Council of 9 March 2011 laying Down Harmonised Conditions for the Marketing of Construction Products and Repealing Council Directive 89/106/EEC (Text with EEA Relevance), Official Journal of the European Union, Strasbourg.

[2] De Geetere, L., Ingelaere, B. (2014). A new building acoustical concept for lightweight timber frame constructions. Internoise, 43rd International Congress on Noise Control Engineering, p. 1-8.

[3] Höglmeier, K., Weber-Blaschke, G., Richter, K. (2017). Potentials for cascading of recovered wood from building deconstruction-A case study for south-east Germany. Resources, Conservation and Recycling, vol. 117, p. 304-314, Dol:10.1016/j.resconrec.2015.10.030.

[4] Asdrubali, F., Ferracuti, B., Lombardi, L., Guattari, C., Evangelisti, L., Grazieschi, G. (2017). A review of structural, thermo-physical, acoustical, and environmental properties of wooden materials for building applications. Building and Environment, vol. 114, p. 307-332, D0l:10.1016/j. buildenv.2016.12.033.

[5] Ministry of Infrastructure (2018). Amendment to Long-Term Strategy for Mobilising Investments in the Energy Renovation Of Buildings, from: https://www.energetika-portal.si/ fileadmin/dokumenti/publikacije/dseps/dopolnitev_dseps_ feb_2018.pdf accessed on 2019-06-08. (in Slovene)

[6] Adekunle, T. 0. and Nikolopoulou, M. (2016). Thermal comfort, summertime temperatures and overheating in prefabricated timber housing. Building and Environment, vol. 103, p. 21-35, D0I:10.1016/j.buildenv.2016.04.001.

[7] Intergovernmental Panel on Climate Change, (2018). Global Warming of $1.5^{\circ} \mathrm{C}$, from:https://unfccc.int/news/unfcccsecretariat-welcomes-ipcc-s-global-warming-of-15degc-report, accessed on 2019-05-12.

[8] Hajat, S., Vardoulakis, S., Heaviside, C. and Eggen, B. (2014). Climate change effects on human health: projections of temperature-related mortality for the UK during the 2020s, 2050s and 2080s. Journal of Epidemiology and Community Health, vol. 68, no. 7, p. 641-648, D0l:10.1136/jech-2013202449.

[9] Eurostat. (2012). Share of Population Living in a Dwelling Not Comfortably Cool during Summer Time by Income Quintile and Degree of Urbanization, from:https://ec.europa.eu/eurostat/ 
data/database?node_code=ilc_hcmp03, accessed on 201904-04.

[10] Pajek, L., Hudobivnik, B., Kunič, R. and Košir, M. (2017). Improving thermal response of lightweight timber building envelopes during cooling season in three European locations. Journal of Cleaner Production, vol. 156, p. 939-952, D0I:10.1016/j.jclepro.2017.04.098.

[11] Arkar, C., Domjan, S. and Medved, S. (2018). Lightweight composite timber façade wall with improved thermal response. Sustainable Cities and Society, vol. 38, p. 325-332, DOI:10.1016/j.scs.2018.01.011.

[12] EPBD 2010/31/EU, Directive 2010/31/EU of the European Parliament and of the Council of 19 May 2010 on the energy performance of buildings, from: https://eur-lex.europa.eu/ LexUriServ/LexUriServ.do?uri=0J:L:2010:153:0013:0035:EN: PDF, accessed on 2019-02-07.

[13] PURES (2010). Rules on efficient use of energy in buildings with a technical guideline (0.J. RS, no. 52/10 and 61/17 GZ), from: https://www.uradni-list.si/glasilo-uradni-list-rs/ vsebina/98727, accessed on 2019-02-07. (In Slovene)

[14] Slovenian Environmental Public Fund - ECO Fund. (2017). Conditions for obtaining grants in the construction or purchase of almost zero-energy new one or two-dwelling, from: https://www.ekosklad.si/fizicne-osebe/nameni/prikazi/ actionID=155, accessed on 2019-04-25. (in Slovene)

[15] TSG-12640-001:2008. Technical Guideline for Health Facilities. Ministry of Health of Republic of Slovenia. (In Slovene)

[16] Rules on the ventilation and air-conditioning of buildings (0.J, no. 42/02) (2002). from: http://pisrs.si/Pis.web/ pregledPredpisa?id=PRAV4223, accessed on 2019-04-25. (in Slovene)

[17] ANSI/ASHRAE Standard 55-2013. Thermal Environmental Conditions for Human Occupancy. American Society Of Heating, Refrigerating And A-C Engineers, Atlanta.

[18] EN 15251:2007:E. Indoor Environmental Input Parameters for Design and Assessment of Energy Performance of Buildings Addressing Indoor Air Quality, Thermal Environment, Lighting and Acoustics. European Committee for Standardization, Brussels.

[19] Manzano-Agugliaro, F., Montoya, F. G., Sabio-Ortega, A. and García-Cruz, A. (2015). Review of bioclimatic architecture strategies for achieving thermal comfort. Renewable and Sustainable Energy Reviews, vol. 49, p. 736-755, Dol:10.1016/j.rser.2015.04.095.

[20] Osterman, E., Butala, V. and Stritih, U. (2015). PCM thermal storage system for 'free' heating and cooling of buildings. Energy and Buildings, vol. 106, p. 125-133, D0l:10.1016/j. enbuild.2015.04.012.

[21] Orel, B., Maček, M., Krainer, A. (1993). Advanced phase change (PCM) materials for heat storage applications in buildings. Solar Energy and Architectural Urban Planning Proceedings at International Conference, p. 111-114.

[22] DesignBuilder Software Ltd. (2107). DesignBuilder Software Ltd - Home, from: https://designbuilder.co.uk//, accessed on 2019-04-25.
[23] Phase Change (2018). BioPCM-Data-Sheet-Q27, from: https:// phasechange.com/technology/data-sheets/, accessed on 2019-04-26.

[24] Phase Change (2018). BioPCM-Data-Sheet-Q25, from: https:// phasechange.com/technology/data-sheets/, accessed on 2019-04-26.

[25] Phase Change (2018). BioPCM-Data-Sheet-Q23, from: https:// phasechange.com/technology/data-sheets/, accessed on 2019-04-26.

[26] Phase Change (2017). Phase Change Materials. from: https:// phasechange.com/wp-content/uploads/2017/06/PhaseChange-Materials-BioPCMs-vs-Salt-Hydrates.pdf, accessed on 2019-04-25.

[27] Knauf (2016). Generic Heat Storage Capacity Knauf Comfortboard 23, from: http://micronal-pcm-app.de/ files/2016-04-16_-_generic_heat_storage_capacity_ comfortboard_23.pdf, accessed 2019-04-25.

[28] ISO 7726:1998. Ergonomics of the thermal environment Instruments for measuring physical quantities, International Organization for Standardization, Geneve.

[29] Soares, N., Gaspar, A. R., Santos, P., Costa, J. J. (2014). Multi-dimensional optimization of the incorporation of PCMdrywalls in lightweight steel-framed residential buildings in different climates. Energy and Building, vol. 70, p. 411-421, D0I:10.1016/j.enbuild.2013.11.072.

[30] Albatici, R., Genetti, F. and Marinelli, M. (2015). Summer comfort in exposed concrete free running buildings. Energy Procedia, vol. 78, p. 2935-2940, D0I:10.1016/j. egypro.2015.11.671.

[31] Mlakar, J., Štrancar, J. (2011). Overheating in residential passive house: Solution strategies revealed and confirmed through data analysis and simulations. Energy and Buildings, vol. 43, no. 6, p. 1443-1451, D0l:10.1016/j. enbuild.2011.02.008.

[32] Stazi, F., Bonfigli, C., Tomassoni, E., Di Perna, C. and Munafò, P. (2015). The effect of high thermal insulation on high thermal mass: Is the dynamic behaviour of traditional envelopes in Mediterranean climates still possible. Energy and Buildings, vol. 88, p. 367-383, D0I:10.1016/j.enbuild.2014.11.056.

[33] Jones, R. V. Goodhew, S. and De Wilde, P. (2016). Measured indoor temperatures, thermal comfort and overheating risk: Post-occupancy evaluation of low energy houses in the UK. Energy Procedia, vol. 88, p. 714-720, Dol:10.1016/j. egypro.2016.06.049.

[34] Vik, T. A., Madessa, H. B., Aslaksrud, P. Folkedal, E. and Øvrevik, 0. S. (2017). Thermal Performance of an Office Cubicle Integrated with a Bio-based PCM: Experimental Analyses. Energy Procedia, 8th International Conference on Sustainability in Energy and Buildings, vol. 111, p. 609-618, DOl:10.1016/j.egypro.2017.03.223.

[35] Reddy, K., Mudgal, V., Mallick, T., Reddy, K.S., Mudgal, V., Mallick, T.K. (2017). Thermal performance analysis of multiphase change material layer-integrated building roofs for energy efficiency in built-environment. Energies, vol. 10, no. 9, p. 1367, DOl:10.3390/en10091367.

[36] Lomas, K.J., Porritt, S.M. (2017). Overheating in buildings: lessons from research. Building Research \& Information, vol. 45, no. 1-2, p. 1-18, D0I:10.1080/09613218.2017.1256136. 
[37] Gasparrini, A., Yuming Guo, Y., Hashizume, M., Lavigne, E., Zanobetti, A., Schwartz, J., Tobias, A., Tong, S., Rocklöv, J., Forsberg, B., Leone, M., De Sario, M., L Bell, M., Leon Guo, Z. L., Wu, C., Kan, H., Yi, S. M., De Sousa Zanotti Stagliorio Coelho, M., Nascimento Saldiva, P. H., Honda, Z., Kim, H. (2015). Mortality risk attributable to high and low ambient temperature: A multicountry observational study. Lancet, vol. 386, no. 9991, p. 369-375, Dol:10.1016/S01406736(14)62114-0.

[38] Jamil, H., Alam, M., Sanjayan, J., Wilson, J. (2016). Investigation of PCM as retrofitting option to enhance occupant thermal comfort in a modern residential building. Energy and Buildings, vol. 133, p. 217-229, D0l:10.1016/j. enbuild.2016.09.064.

[39] Panayiotou, G.P., Kalogirou, S.A., Tassou, S.A. (2016). Evaluation of the application of phase change materials (PCM) on the envelope of a typical dwelling in the Mediterranean region. Renewable Energy, vol. 97, p. 24-32, D0I:10.1016/j. renene.2016.05.043.

[40] Krainer A. (2008). Passivhaus contra bioclimatic design. Bauphysik, vol. 30, no. 6, p. 393-404, D0l:10.1002/ bapi.200810051. 